\title{
Poučavanje teme Prehrana čovjeka putem istraživačkog učenja i osnovnih načela teorije izbora i kvalitetne škole
}

\author{
Ana Petelinec, Ema Nikša, Dominik Grudiček, Mirela Sertić Perić \\ Sveučilište u Zagrebu, Prirodoslovno-matematički fakultet, Biološki odsjek, Zagreb, Hrvatska; ORCID: 0000-0002-4744-7884 \\ apetelinec@stud.biol.pmf.hr
}

\section{SAŽETAK}

Nepravilna prehrana je sve veći problem u modernim društvima, a javlja se već kod djece i adolescenata. Glavni cilj ovog rada je ukazati na metode i oblike poučavanja pomoću kojih se može osvijestiti važnost pravilne prehrane kod djece osnovnoškolskog uzrasta. Provedeno je učeničko istraživanje prehrane učenika petog $i$ sedmog razreda osnovne škole, kako bi se utvrdio dnevni broj obroka i raznolikost prehrane učenika, a na osnovu rezultata istraživanja, učenike se - kroz prilagodbu nastavnih aktivnosti interesima učenika - vodilo u učenju o zdravim prehrambenim navikama. Rezultati učeničkog istraživanja pokazali su da učenici koji su sudjelovali u istraživanju konzumiraju najmanje tri obroka i barem jednu vrstu voća ili povrća dnevno, što povezujemo s prethodnim istraživanjima koja tumače da na prehrambene navike djece i mladih uvelike utječu različiti okolišni čimbenici, poput prehrambenih navika roditelja, tradicije i medija. Rezultati učeničkog istraživanja poslužili su kao osnova za daljnje poučavanje o temi pravilne prehrane čovjeka, odnosno za izgradnju predviđenih bioloških koncepata i učeničkih stavova te za razvijanje sposobnosti primjene usvojenih znanja o prehrani na primjerima iz svakodnevnog života. Kroz sve nastavne aktivnosti opisane u ovom radu, učenici su pokazali interes za temu pravilne prehrane i voljni su razviti zdravije prehrambene navike, a mi iznosimo mišljenje da bi se to moglo i postići primjenom osnovnih načela kvalitetne škole i teorije izbora u nastavi, koji se temelje na tome da učenici samostalno odabiru svoje buduće ponašanje i/ili korigiraju postojeće navike temeljem informacija koje samostalno prikupe i obrade. U jednom dijelu ovog istraživanja, nastavni sadržaj je prilagođen interesu učenika, što je rezultiralo velikom aktivnošću učenika, ukazujući na pozitivne učinke primjene načela kvalitetne škole $i$ teorije izbora u nastavi biologije. Sugeriramo da bi sudjelovanje učenika u kreiranju nastave vjerojatno pomoglo u stvaranju kvalitetnijeg odnosa između učenika i nastavnika i pozitivnijeg okruženja za učenje, što je također jedna od osnovnih postavki kvalitetne škole. Također, veća uključenost učenika u kreiranje nastave može poslužiti i kao podrška u izgradnji (pozitivnih) stavova učenika, odnosno kao poticaj na pozitivne promjene u ponašanju (izboru prehrambenih namirnica) učenika. Nadalje, temeljem rezultata ovog istraživanja, predlažemo da nastavnici detaljno bilježe učeničku aktivnost tijekom nastavnih sati, što bi im moglo pomoći u samoprocjeni vlastitog rada, kao i u procjeni učeničkog interesa za pojedine nastavne teme i oblike rada.

Ključne riječi: prehrana učenika; nastava biologije; istraživački rad učenika; mogućnost izbora

\section{UVOD}

Jedan od glavnih problema današnjice je kvaliteta prehrane djece i adolescenata. Djeca i mladi skloni su preskakati obroke i hraniti se "nezdravom" (brzom) hranom, što dolazi do izražaja tijekom adolescencije te se često povezuje i s porastom indeksa tjelesne mase (engl. body mass indeks, BMI) pojedinaca (Braithwaite i sur, 2014; Dobročinac i sur, 2019), posebice ako nisu fizički aktivni i provode sjedilački način života. Takvi suvremeni obrasci prehrane kod djece i mladih ukazuju da bi u suvremenom odgoju i obrazovanju trebalo usmjeriti pažnju na stvaranje dobrih prehrambenih navika. Teme vezane uz zdravu prehranu te proizvodnju i potrošnju hrane mogu se iščitati iz ishoda predmetnih kurikuluma Prirode (Ministarstvo znanosti i obrazovanja, 2019a) i Biologije (Ministarstvo znanosti i obrazovanja, 2019b) te iz očekivanja međupredmetnih tema Zdravlje (Ministarstvo znanosti i obrazovanja, 2019c) i Održivi razvoj (Ministarstvo znanosti i obrazovanja, 2019d). Jedan od načina 
ostvarivanja ishoda i očekivanja, odnosno ključnih sadržaja istaknutih u kurikulumskim dokumentima vezanih uz temu zdrave ishrane jest provođenje učeničkih istraživačkih projekata, kroz koje učenici mogu pratiti i bilježiti svoju prehranu i na kraju sami doći do zaključka koji će im omogućiti promjenu stavova i navika o prehrani. Na taj način se $u$ istraživački rad učenika ugrađuju i osnovna načela teorije izbora, jer se učenici izlažu situaciji da sami prikupe informacije o svojim navikama, sami odabiru kako će filtrirati i/ili percipirati prikupljene informacije i u konačnici sami odlučuju način na koji će (svojim ponašanjem, starim ili novim navikama) odgovoriti na prikupljene informacije (Glasser, 1990).

Prema Glasseru (1990) i njegovoj teoriji izbora, sami odabiremo sva svoja ponašanja koristeći prava na osobnu slobodu, koja omogućuju odabir odgovornijeg ponašanja i život lišen krivnje zbog neodgovornog ponašanja. Također, Glasserova (1990) teorija ukazuje da nas nitko ne može "natjerati“ da učinimo ili osjetimo bilo što, jer sve što radimo proizlazi iz vlastitog doživljaja i shvaćanja primljenih informacija. Prema osnovnim načelima teorije izbora bazirana je i tzv. kvalitetna škola (Glasser, 2005). Kvalitetna škola cjelovit je sustav programa i aktivnosti u području odgoja i obrazovanja, čiji je osnovni cilj potaknuti primjenu ideja teorije izbora, odnosno suradničkog učenja i poučavanja bez prisile, uz međusobno uvažavanje i motiviranje učenika i učitelja (Glasser, 1999, 2005).

U kvalitetnoj školi, naglasak se stavlja na aktivno učenje. Aktivno učenje je usmjereno na učenika (Dewey, 1997) i „ppolazi od osnovne pretpostavke da je učenje po prirodi aktivno nastojanje koje teži samostalnom učenju onoga koji uči, a ne učenju koje se odvija kroz prijenos informacija“ (Gazibara, 2018). Suradničko učenje i poučavanje, istraživačko učenje, učenički projekti i slične metode i oblici poučavanja sastavni su dio nastave u kvalitetnoj školi, kojima je cilj stvoriti pozitivno okruženje za učenje (Vrcelj, 2015). U takvom okruženju, učenici školu ne doživljavaju kao stres ili prisilu, već kao mjesto u kojem imaju ugodno i poticajno okruženje za kvalitetan rad. Odnosno, učenici postaju svjesni da ih škola potiče da nauče i svladaju puno toga što im može pomoći u životu i unaprijediti kvalitetu života. Uz stvaranje takvih pozitivnih emocija, učenici će svjesno izabrati da aktivno sudjeluju u nastavi, kako bi naglasili sve svoje kvalitete, a pritom osjećali i ugodu (Glasser, 1999; Wubbolding, 2007).

Primjenom osnovnih načela teorije izbora i kvalitetne škole u nastavi možemo utjecati na poboljšanje psihičkog i fizičkog zdravlja učenika. Johnson i sur. (2002) proveli su istraživanje nad adolescentima prosječne starosti 13,8 godina, kojim su dokazali da poremećaji u prehrani mogu biti povezani sa povećanim rizikom nastanka velikog spektra fizičkih i psihičkih bolesti. Dakle, vrlo je važno - u poticajnom školskom okruženju - kod djece i adolescenata razviti svijest o zdravim prehrambenim navikama, koje mogu imati veliki utjecaj na fizičko i na psihičko zdravlje čovjeka. Važno je osvijestiti da vlastiti odabir nepravilne prehrane može dovesti do stvaranja loših prehrambenih navika, neprimjerene tjelesne mase, ali i do poremećaja u prehrani i ovisnosti o nezdravim namirnicama, koji najčešće nastaju zbog psihičkih ili emocionalnih problema (Fairburn, 2008).

Glavni cilj ovog rada je ukazati na metode i oblike poučavanja pomoću kojih se može osvijestiti važnost pravilne prehrane kod djece osnovnoškolskog uzrasta. Specifični ciljevi rada bili su: (i) iznijeti detalje provedbe i rezultate istraživačkog rada učenika, uklopljenog u nastavu Prirode (u petom razredu osnovne škole) i Biologije (u sedmom razredu osnovne škole), temeljenog na prikupljanju podataka o prehrambenim navikama učenika; (ii) odgovoriti na pitanje hoće li primjena osnovnih načela teorije izbora u nastavi Biologije potaknuti učenike sedmog razreda osnovne škole na izbor zdravih prehrambenih namirnica. Polazne pretpostavke bile su da: (i) učenici konzumiraju najmanje tri obroka i barem jednu vrstu voća ili povrća dnevno, što će poslužiti kao osnova za daljnje poučavanje o temi pravilne prehrane čovjeka, odnosno potaknuti izgradnju predviđenih bioloških koncepata i učeničkih 
stavova te razvijanje sposobnosti primjene usvojenih znanja o prehrani na primjerima iz svakodnevnog života, (ii) će primjena osnovnih načela teorije izbora i kvalitetne škole u nastavi Biologije potaknuti učenike na razmišljanje o izboru zdravih prehrambenih namirnica.

\section{METODE}

Istraživački rad, kojim su učenici prikupljali podatke o svojim prehrambenim navikama proveden je $\mathrm{s}$ 15 učenika petog razreda jedne osnovne škole u Varaždinu i 20 učenika sedmog razreda osnovne škole u Zagrebu.

Učenici petog razreda osnovne škole $(\mathrm{N}=15)$ su tijekom 21 dana (tri tjedna) bilježili količinu i vrstu hrane koju su konzumirali. Oblikovali su tablicu, u koju su za svaki dan bilježili koje i koliko obroka su taj dan imali i što su pojeli. Učenici su u tablicu unosili i svoje mišljenje o tome je li pojedini obrok zdrav, tako da su uz opis obroka upisali kvačicu (za obrok koji su smatrali zdravim) ili križić (za obrok koji su smatrali nezdravim). Učenici su bilježili samo hranu koju su konzumirali, dok konzumacija napitaka nije bilježena. Organizacija i dizajn tablice bile su slobodna volja učenika i produkt njihovih ideja i kreativnosti. Nakon završetka učeničkog istraživanja, rezultati su analizirani u sklopu nastave Prirode, prilikom ostvarivanja odgojno-obrazovnog ishoda OŠ PRI C.5.1. Učenik razlikuje najvažnije izvore $i$ oblike energije i raspravlja o njihovu utjecaju na život na Zemlji (Ministarstvo znanosti i obrazovanja, 2019a), uz nastavnu temu Prehrana čovjeka. U prvom dijelu sata komentirani su podaci dobiveni istraživačkim radom učenika, a u drugom dijelu sata učenicima je prikazan videozapis na temu pravilne prehrane čovjeka, u kojem su definirani dnevni broj obroka, preporučena količina hrane, razlika u energetskoj vrijednosti pojedinih namirnica te je istaknuta važnost doručka koji se ne bi trebao preskakati. Nakon gledanja videozapisa, učenici su odgovarali na pitanja vezana uz pravilnu prehranu i prikazani videozapis. Neka od postavljenih pitanja bila su: „Je li poželjno preskakati doručak?“, „Je li prihvatljivo stalno jesti 5 ili 6 istih namirnica ili je poželjno da nam prehrana bude raznolika?", „Komentiraj poslovicu: doručkuj kao car, ručaj kao kralj i večeraj kao siromah!“ i „Objasni pojam šareni tanjur!“. Odgovori učenika su raspravljeni kroz razgovor s učenicima.

Budući da je s učenicima sedmog razreda $(N=20)$ dodatni cilj bio primijeniti osnovna načela teorije izbora u nastavi Biologije, s njima je proveden je malo drugačiji tijek nastave nego s učenicima petog razreda, i to prilikom ostvarivanja odgojno-obrazovnog ishoda BIO OŠ B.7.2. Analizira utjecaj životnih navika i rizičnih čimbenika na zdravlje organizma ističući važnost prepoznavanja simptoma bolesti $i$ pravovremenoga poduzimanja mjera zaštite (Ministarstvo znanosti i obrazovanja, 2019b), uz nastavnu temu Pravilna prehrana. Nastava s učenicima sedmog razreda osnovne škole se temeljila na dva dvosata. Na početku prvog dvosata, učenici su ispunjavali anonimnu anketu „Moje svakodnevne navike" (u obliku Google Form obrasca pomoću svojih tableta ili mobilnih uređaja), gdje su odgovarali na pitanja o svojim prehrambenim navikama (broju obroka u danu, fizičkoj aktivnosti, vrsti namirnica koje konzumiraju i sl.) (prilog 1). Nakon ispunjavanja ankete, s učenicima je pokrenuta debata na temu pravilne prehrane, koja je vezana uz osobni doprinos očuvanju zdravlja (prema preporukama za ostvarenje odgojno-obrazovnih ishoda u sklopu kurikuluma za nastavni predmet Biologija za osnovne škole; Ministarstvo znanosti i obrazovanja, 2019b). Ovisno o interesu i reakcijama učenika tijekom debate, student-nastavnik je moderirao raspravu. Tijekom debate, učenici su razgovarali o hranjivim tvarima i pravilnoj prehrani s naglaskom na važnost konzumacije raznovrsnih namirnica te su međusobno usporedili svakodnevni izbor hrane. Nakon debate, učenici su iznijeli glavne zaključke i poruke proizišle iz provedene debate, pri čemu su istaknuli povezanost životnih navika, pravilne prehrane i tjelesne aktivnosti s bolestima. Potom su učenici ispunili anketu „Moje mišljenje o temi 
Pravilna prehrana" (prilog 2), kroz koju su iskazali zadovoljstvo provedenim dvosatom te koliko ih je sat motivirao za daljnje istraživanje teme i potakao na razmišljanje o zdravim navikama te su istaknuli što su naučili novo, a o kojim vezanim temama bi voljeli doznati više.

Nadalje, nekoliko zainteresiranih učenika $(\mathrm{N}=8)$ su dobili zadatak da tijekom tri dana prate svoje prehrambene navike. Bilježili su koje i koliko obroka su svakoga dana imali, količinu i vrstu hrane koju su konzumirali te su procjenjivali zastupljenost ugljikohidrata, masti i bjelančevina u pojedinom obroku. Zastupljenost hranjivih tvari u obrocima učenici su određivali po osobnoj procjeni, što je ujedno bio i način provjeravanja ostvarenosti ishoda vezanih uz prethodni nastavni sat (dvosat) Pravilna prehrana. Za osobnu procjenu zastupljenosti pojedinih hranjivih tvari u obrocima, učenici su koristili relativnu skalu od 0 do 2 , gdje 0 označava da učenici smatraju da u obroku nema pojedinih hranjivih tvari, a 2 označava da učenici smatraju da pojedine hranjive tvari dominiraju u obroku. Nakon provedbe učeničkog istraživanja je uslijedio drugi dvosat, tijekom kojega su učenici najprije prezentirali rezultate svog trodnevnog istraživanja, a potom je uslijedio razgovor s učenicima. Kroz vođeni razgovor, učenici su na primjeru vlastitog istraživanja ponajprije ponovili osnovne postavke istraživačkog rada učenika, pri čemu je naglasak stavljen na mali broj ispitanika koji su sudjelovali u istraživanju, odnosno na utjecaj malih uzoraka na rezultate istraživanja. Zatim je, kroz vođenu raspravu s učenicima i analizu rezultata učeničkog istraživanja, istaknuta važnost pravilne prehrane i njena povezanost sa sprječavanjem razvoja poremećaja u prehrani (stoga se ovaj dvosat u nastavku teksta navodi kao dvosat na temu Poremećaji u prehrani). Potom su učenici u grupama istraživali poremećaje u prehrani pretraživanjem dostupnih informacija na internetu. Grupe su formirane u virtualnom obliku, pomoću aplikacije Microsoft Office Teams uslijed online modela nastave, odnosno prema preporukama za rad u uvjetima povezanima s COVID-19 epidemijom (Ministarstvo znanosti $i$ obrazovanja, 2020). Za kraj dvosata, učenici koji su bili na nastavi $(N=16)$ su rješavali kviz o prehrani putem internetske stranice Socrative (prilog 3), a zatim i anketu "Moje mišljenje o temi prehrana“ (prilog 2), istovjetnu onoj koju su ispunjavali učenici petog razreda osnovne škole.

Osim anketiranjem, zainteresiranost i aktivnost učenika na nastavi mjerena je tako da je brojano koliko su puta učenici odgovarali na postavljena pitanja, davali komentare i postavljali pitanja. Obzirom da pitanja nisu standardizirana, u obzir je uzeta sva ostvarena komunikacija s učenicima. Dobiveni rezultati analizirani su u programu Microsoft Office Excel.

\section{REZULTATI}

\section{Istraživanje prehrane djece i adolescenata}

Svi anketirani učenici petog razreda imali su najmanje tri obroka dnevno - doručak, ručak i večeru. Glavnina učenika ima četiri obroka dnevno. Uz glavne obroke, učenici imaju 1 do 2 međuobroka. Učenici sedmog razreda u prosjeku imaju četiri obroka dnevno, međutim pojedini učenici imaju pet ili više obroka. Međuobroci kod učenika nisu dobro definirani, ne konzumiraju se svaki dan niti u isto doba dana. Skupine namirnica koje su učenici petog razreda naveli da konzumiraju tijekom dana prikazane su u tablici 1. 
Tablica 1 Zbirni prikaz namirnica koje su učenici petog razreda osnovne škole konzumirali tijekom tri tjedna u pojedinim dnevnim obrocima

\begin{tabular}{|c|c|c|c|c|}
\hline \multirow{2}{*}{ Skupina namirnica } & \multicolumn{4}{|c|}{ Dnevni obroci } \\
\hline & Doručak & Ručak & Večera & Međuobrok \\
\hline $\begin{array}{c}\text { Žitarice i namirnice } \\
\text { bogate škrobom }\end{array}$ & Kruh, cjelovite žitarice & $\begin{array}{l}\text { Kruh, tjestenina, riža, } \\
\text { krumpir }\end{array}$ & $\begin{array}{l}\text { Kruh, tjestenina, riža, } \\
\text { krumpir, cjelovite } \\
\text { žitarice }\end{array}$ & Žitarice, pecivo \\
\hline Voće i povrće & $\begin{array}{c}\text { Naranča, mandarina, } \\
\text { zelena salata, paprika, } \\
\text { krastavac }\end{array}$ & $\begin{array}{c}\text { Zelena salata, krastavac, } \\
\text { paprika, rajčica, kelj, luk, } \\
\text { kupus, grah }\end{array}$ & $\begin{array}{l}\text { Naranča, mandarina, } \\
\text { zelena salata, paprika, } \\
\text { krastavac, kupus, grah }\end{array}$ & $\begin{array}{l}\text { Naranče, mandarine, } \\
\text { jabuke, kruške, banane }\end{array}$ \\
\hline $\begin{array}{l}\text { Mliječni i mesni } \\
\text { proizvodi }\end{array}$ & $\begin{array}{l}\text { Mlijeko, sir, vrhnje, } \\
\text { jogurt, meso, jaja, } \\
\text { salama }\end{array}$ & $\begin{array}{l}\text { Mlijeko, sir, vrhnje, } \\
\text { meso, riba, jaja }\end{array}$ & $\begin{array}{l}\text { Mlijeko, sir, vrhnje, } \\
\text { jogurt, meso, jaja, } \\
\text { salama }\end{array}$ & Mlijeko, jogurt \\
\hline Masti i ulja & $\begin{array}{l}\text { Maslac, margarin, } \\
\text { suncokretovo ulje, } \\
\text { bućino ulje, svinjska } \\
\text { mast }\end{array}$ & $\begin{array}{c}\text { Suncokretovo ulje, } \\
\text { bućino ulje, svinjska } \\
\text { mast }\end{array}$ & $\begin{array}{l}\text { Suncokretovo ulje, } \\
\text { bućino ulje, svinjska } \\
\text { mast }\end{array}$ & $\begin{array}{l}\text { Biljno ulje, maslac, } \\
\text { margarin }\end{array}$ \\
\hline Rafinirani šećeri & $\begin{array}{l}\text { Čokoladne pahuljice, } \\
\text { čokolada, pekmez }\end{array}$ & Kolač, čokolada, keks & Čokoladne pahuljice & Kolač, keks \\
\hline
\end{tabular}

Na slici 1 prikazana je usporedba prosječnog broja obroka učenika petog i sedmog razreda. $40 \%$ učenika sedmog razreda ima prosječno tri obroka dnevno, dok 45 \% učenika ima 5 ili više obroka. Među učenicima petog razreda, većina (53\%) ih ima četiri obroka dnevno.

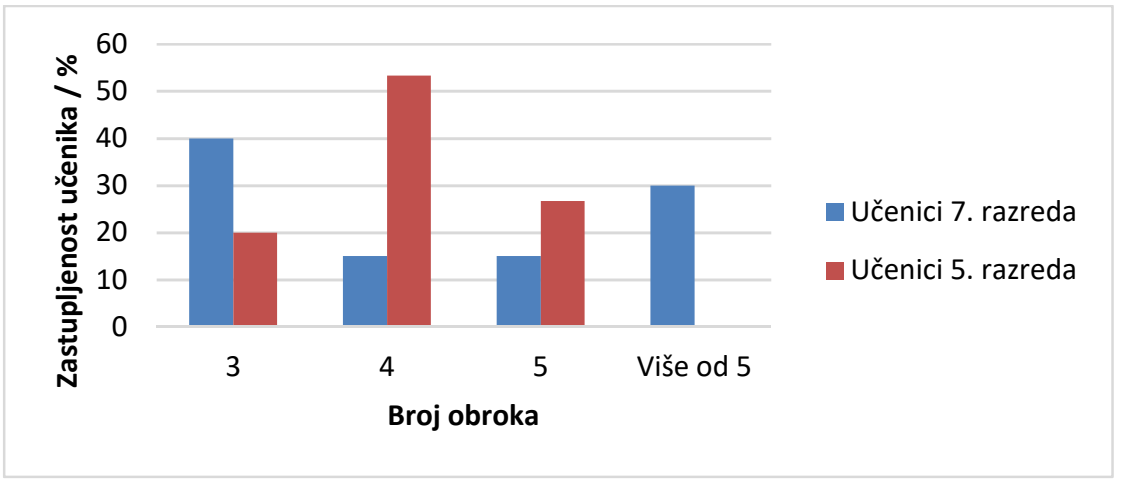

Slika 1 Usporedba prosječnog broja obroka učenika petog $(N=15)$ i sedmog $(N=20)$ razreda osnovne škole koji su sudjelovali u istraživanju

\section{Obroci učenika}

Doručak je obrok koji konzumiraju gotovo svi učenici petog razreda. Raznolikost i udio namirnica iz skupine povrća i voća (13\%) je kod doručka manja nego kod drugih većih obroka (ručak, večera) (tablica 1, slika 2). Opaženo je da su ugljikohidrati (žitarice i namirnice bogate škrobom) najzastupljeniji (43\%) u jutarnjem obroku (slika 2). Ručak je najraznovrsniji i najobilniji obrok, s podjednakim udjelima žitarica i škrobnih namirnica (32\%), voća i povrća (30\%), mliječnih i mesnih proizvoda (27 \%) (slika 2). Mliječni i mesni proizvodi su s relativno visokim udjelom (10-30 \%) zastupljeni u većini obroka. U večeri su najzastupljenije žitarice i namirnice bogate škrobom (35\%), dok su voće i povrće (26\%) te mliječni i mesni proizvodi ( $25 \%$ ) zastupljeni podjednako. U međuobrocima je najzastupljenija skupina namirnica voće i povrće (61\%), no iz slike 2 je vidljiva povećana konzumacija namirnica bogatih rafiniranim šećerom (15\%) u odnosu na ostale obroke. 


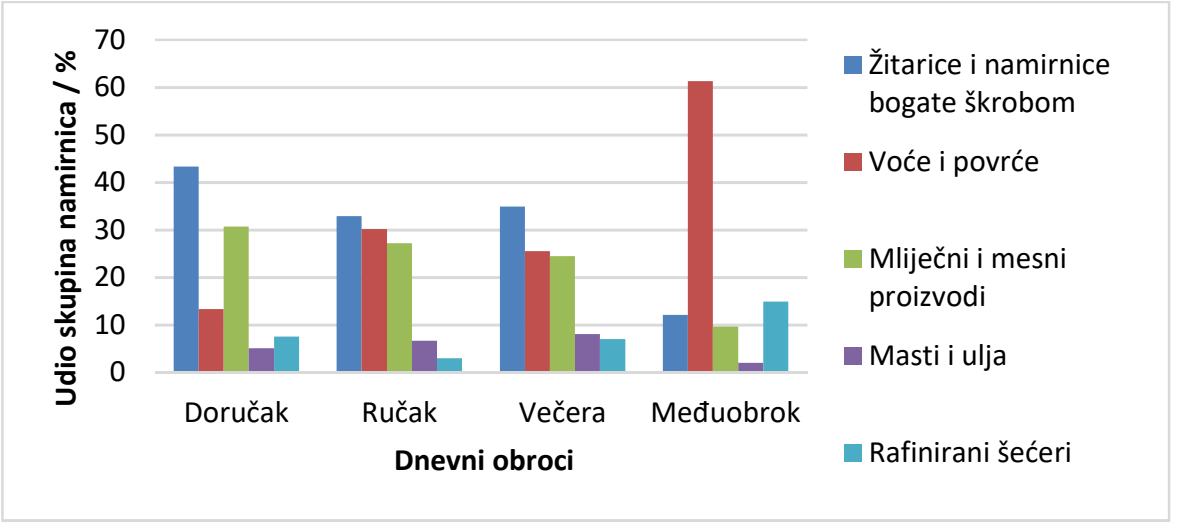

Slika 2 Zastupljenost pojedinih skupina hranjivih tvari u dnevnim obrocima učenika petog razreda osnovne škole koji su sudjelovali u istraživanju

Iz slike 3 vidljivo je da u prehrani učenika petog razreda koji su sudjelovali u istraživanju prevladavaju ugljikohidrati - ponajviše žitarice (32\%) i voće i povrće (31\%), dok je udio rafiniranih šećera (8\%) relativno nizak. Bjelančevine učenici uglavnom dobivaju kroz mesne i mliječne proizvode, koji su zastupljeni s $24 \%$ u prehrani učenika. Udio masti i ulja (6 \%) je relativno nizak.

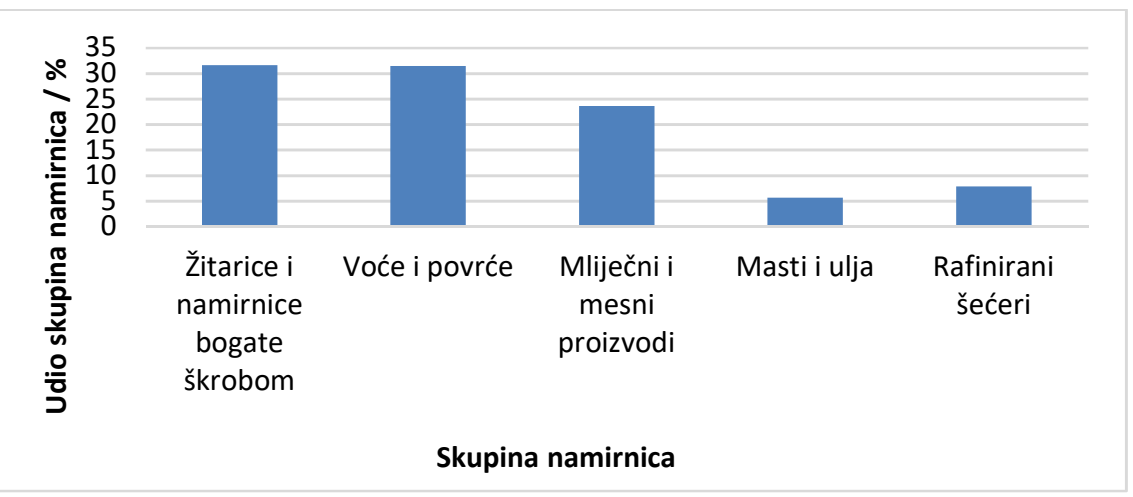

Slika 3 Zastupljenosti pojedinih skupina namirnica u prehrani učenika petog razreda osnovne škole koji su sudjelovali u istraživanju

Iz slike 4. opaža se da su učenici sedmog razreda osnovne škole koji su proveli istraživanje procijenili da u njihovim obrocima prevladavaju ugljikohidrati i bjelančevine, dok masti smatraju manje zastupljenima.

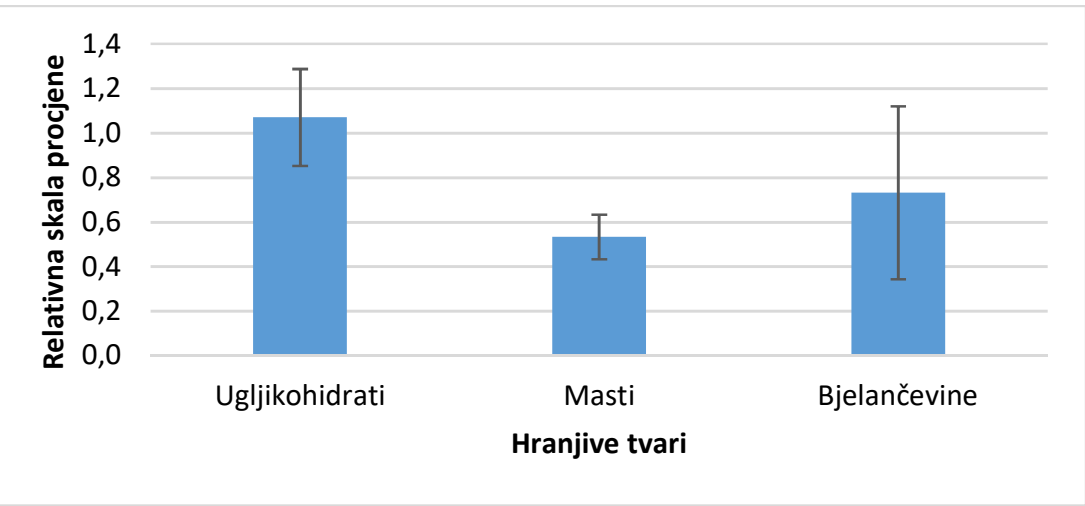

Slika 4 Prosječne vrijednosti ( \pm SD) zastupljenosti pojedinih hranjivih tvari u obrocima učenika sedmog razreda osnovne škole koji su sudjelovali u istraživanju. Prosječne vrijednosti su izračunate prema osobnoj procjeni učenika, koji su za procjenu koristili relativnu skalu raspona od 0 do 2, gdje 0 označava da učenici smatraju da u obroku nema pojedinih hranjivih tvari, a 2 označava da učenici smatraju da pojedine hranjive tvari dominiraju u obroku 


\section{Primjena osnovnih načela teorije izbora u nastavi Biologije}

Rezultati ankete "Moje svakodnevne navike"

Anketni upitnik "Moje svakodnevne navike" je ispunilo 20 učenika sedmog razreda osnovne škole. 75 $\%$ učenika bavi se sportom (fizički je aktivno). 45 \% učenika navodi da svakodnevno ima međuobroke, a $55 \%$ ponekad. U prosjeku, učenici imaju četiri obroka dnevno. Prema odgovorima iz ankete, $20 \%$ učenika svakodnevno konzumira voće i povrće. $15 \%$ učenika razmišlja je li hrana koju jedu zdrava, dok 30 \% uopće ne razmišlja. 50 \% učenika navodi da želi promijeniti svoju prehranu. Na pitanje kako bi htjeli promijeniti svoju prehranu, učenici odgovaraju da bi htjeli konzumirati više voća i povrća i manje šećera. Većina ispitanika (60 \%) izjavila je da bi htjeli naučiti više o zdravoj prehrani i voću i povrću.

\section{Rezultati ankete "Moje mišljenje o temi Pravilna prehrana"}

$\mathrm{U}$ anketi je sudjelovalo samo osam učenika, jer učenici nisu redovno izvršavali svoje obaveze. U anketnim pitanjima otvorenog tipa (prilog 2), 50\% ispitanika reklo je da se na satovima dovoljno razgovaralo o svim temama, a $38 \%$ da je trebalo još razgovarati o pravilnoj prehrani, bjelančevinama i savjetima o prihvaćanju svog fizičkog izgleda te kako promijeniti prehranu. Učenici su većim dijelom (>30 \% učenika; tablica 2 ) potvrdili da su ih nakon nastave počele zanimati teme pravilna prehrana, hranjive tvari i poremećaji u prehrani.

Tablica 2 Zastupljenost učeničkih odgovora na pitanja/tvrdnje iz ankete „Moje mišljenje o temi prehrana“. U anketi je sudjelovalo samo 8 učenika

\begin{tabular}{|c|c|c|c|}
\hline Anketno pitanje/tvrdnja. & \multicolumn{3}{|c|}{ Zastupljenost odgovora / \% } \\
\cline { 2 - 4 } & $\mathrm{Da}$ & $\mathrm{Možda}$ & $\mathrm{Ne}$ \\
\hline Nastavni satovi su me potaknuli da više istražim o temi prehrane. & 37,5 & 62,5 & 0 \\
\hline Nastavni satovi su me potaknuli da više razmišljam o zdravim navikama. & 62,5 & 37,5 & 0 \\
\hline $\begin{array}{c}\text { Nastavni satovi su mi pomogli da shvatim koje navike su mi dobre, a koje bih } \\
\text { trebala promijeniti. }\end{array}$ & 75 & 25 & 0 \\
\hline Nakon ovih nastavnih satova više ću se truditi pravilno se hraniti. & 75 & 25 & 0 \\
\hline Nastavni satovi su me motivirali da se više brinem o svom zdravlju. & 75 & 25 & 0 \\
\hline $\begin{array}{c}\text { Nastavni satovi su me motivirali da prijateljima i obitelji pričam o važnosti pravilne } \\
\text { prehrane. }\end{array}$ & 37,5 & 50 & 12,5 \\
\hline \begin{tabular}{c} 
prem \\
\hline
\end{tabular}
\end{tabular}

Analiza aktivnosti i procjena ostvarenosti ishoda učenja učenika sedmog razreda osnovne škole Prilikom procjene aktivnosti učenika, u obzir su se uzimali učenički odgovori na pitanja, postavljena pitanja i ostali komentari. Primijećeno je da je pet učenika bilo izrazito aktivno tijekom oba dvosata. Tijekom dvosata na temu Pravilna prehrana zabilježeno je 162 aktivnosti učenika, a tijekom dvosata na temu Poremećaji u prehrani 99 aktivnosti. Ostvarenost predviđenih odgojno-obrazovnih ishoda kod učenika sedmog razreda procijenila se pomoću kviza o prehrani putem internetske stranice Socrative (prilog 3), koji je riješilo 16 učenika prisutnih na nastavi. Prosječna riješenost kviza o prehrani je 77 \%. Najbolje riješeno je prvo pitanje (prilog 3), o broju dnevnih obroka, sa $100 \%$ točnih odgovora, a najslabije je bilo riješeno treće pitanje (s 31 \% točnih odgovora), koje se ticalo sastavnica pravilne prehrane.

\section{RASPRAVA}

\section{Prehrana djece i adolescenata}

Istraživanja prehrambenih navika djece $\mathrm{i}$ adolescenata predstavljena u ovom radu su primjerena osnovnoškolskom uzrastu, ali primjenjiva su i na druge uzraste, ovisno o tome kako se određene teme prezentiraju i kako (koliko zahtjevno) se postave određeni zadatci učenicima. Istraživanja o prehrani djece i adolescenata su provedena diljem svijeta (npr. Serra-Majem i sur, 2001; Tanofsky-Kraff i sur, 2007; Braithwaite i sur, 2014; Dobročinac i sur, 2019), a Pala i sur. (2019) su čak razvili i upitnik o 
prehrambenim navikama (engl., Eating Habits Questionnaire, EHQ), zasebno za djecu, adolescente i odrasle, koji su testirani u osam kulturalno različitih europskih zemalja, s ciljem da se u budućnosti koriste za sustavno istraživanje prehrambenih navika i obiteljskog okruženja pojedinaca, koji mogu utjecati na pojavu prekomjerne tjelesne mase i opće obiteljsko zdravlje. Međutim, rijetke publikacije prezentiraju rezultate istraživačkog rada učenika o njihovim prehrambenim navikama, odnosno rijetki radovi ističu metodički značaj istraživanja na temu pravilne prehrane. Premda, iz pregleda literature o prehrambenim navikama među adolescentima, ističe se da su brojna istraživanja među tinejdžerima temeljena na samoprocjeni, odnosno pomoću tzv. self-report instrumenata (Tanofsky-Kraff i sur, 2007), kao što je bio slučaj i u ovom našem radu. Prepoznato je da je takav pristup problematičan, jer adolescenti često podcjenjuju unos pojedinih prehrambenih namirnica i njihovih kalorijskih vrijednosti (Tanofsky-Kraff i sur, 2007) pa bi stoga i rezultati iznijeti u ovom radu također mogli biti pod utjecajem subjektivne procjene djece $\mathrm{i}$ adolescenata koji su sudjelovali u učeničkom istraživanju. Nadalje, na zaključke našeg rada je mogao utjecati i relativno mali broj ispitanika tj. učenika koji su sudjelovali u istraživanju, odnosno nedovoljno reprezentativan uzorak djece i adolescenata određene dobi. Dakle, pri raspravi rezultata učeničkog istraživanja provedenog u ovom radu, vrlo je važno uzeti u obzir subjektivnost učenika, mali broj ispitanika, ali i dobnu razliku među učenicima-sudionicima istraživanja, koji su u prosjeku imali 11 godina (učenici petog razreda osnovne škole) i 13 godina (učenici sedmog razreda osnovne škole).

Provedenim učeničkim istraživanjem potvrđena je polazna pretpostavka da učenici konzumiraju najmanje tri obroka dnevno i barem jednu vrstu voća ili povrća dnevno, što je poslužilo kao osnova za izgradnju koncepata i stavova o prehrani na primjerima iz svakodnevnog života učenika. Uvidom u prehrambene navike većine svojih vršnjaka i naknadnom raspravom o rezultatima njihovog istraživanja, učenici su osvijestili svoje navike, čime ih se potaknulo na pozitivne promjene u njihovom ponašanju (izboru prehrambenih namirnica). Kod učenika petog razreda je opaženo da većina učenika ima četiri obroka dnevno, dok većina učenika sedmog razreda ima tri obroka dnevno, premda ima i onih s više od pet obroka dnevno (što nije opaženo kod učenika petog razreda). Slično našim opažanjima, Dobročinac i sur. (2019) su u istraživanju populacije adolescenata u Vinkovcima opazili da tinejdžeri uglavnom konzumiraju tri ili više obroka dnevno. Također, i Skrzypulec-Plinta i BakSosnowska (2012) opazile su da adolescenti jedu $4 \pm 1$ obroka u danu, što se podudara s rezultatima naših adolescenata. I kod učenika petog i kod učenika sedmog razreda opaža se da u prehrani prevladavaju ugljikohidrati i bjelančevine, uz manju zastupljenost masti. Moguće je da je udio ugljikohidrata i veći nego što je iskazano u rezultatima temeljenima na zapisima naših učenika, jer su učenici bilježili samo konzumiranu hranu (ne i napitke), koji uvelike mogu utjecati na kalorijski unos, a ponajviše na udjele ugljikohidrata u prehrani djece (Tanofsky-Kraff i sur, 2007). Prema prikupljenim podacima, količina i kalorijski unos konzumirane hrane naših učenika je u granicama preporučenih vrijednosti za djecu od 9 do 13 godina starosti (Gidding i sur, 2006), ali o tome se ne može precizno govoriti jer učenici nisu bilježili niti masu konzumiranih namirnica niti unos napitaka pa je izostao i točan kalorijski iznos konzumiranih namirnica. Kod naših učenika, u doručku prevladavaju žitarice i mliječni proizvodi, baš kao što je dokazano u istraživanju koje su s adolescentima provele SkrzypulecPlinta i Bak-Sosnowska (2012). Međutim, u njihovom istraživanju se umjesto žitarica razmatrao kruh te je dokazano da u doručku njihovih ispitanika nema statistički značajne razlike u udjelu kruha i mliječnih proizvoda, ali da je udio ostalih namirnica (poput mesa, voća i povrća) značajno manji. Spomenute analize su bile provedene samo na iskazima onih učenika koji su izjavili da konzumiraju prva dva dnevna obroka - zajutrak i doručak. Naime, u svom istraživanju su doznale da $10 \%$ ispitanika preskače zajutrak, a čak 15 \% ispitanika preskače doručak (Skrzypulec-Plinta i Bak-Sosnowska, 2012). 
Što se tiče ručka, kod naših učenika je to najraznolikiji i najobilniji obrok, u kojem prevladavaju žitarice i namirnice bogate škrobom, mesni proizvodi i povrće, što je u skladu s tradicijom većine europskih zemalja (IDE, 2008).

Izgledno je da na prehrambene navike djece starosti od 6 do 12 godina uvelike utječu podražaji iz okoline, poput roditeljske brige i prehrambenih navika roditelja, tradicijske kulture, medija i reklama te dostupnosti, ponude i mogućih ograničenja hrane (Fisher i sur, 2002; Cecil i sur, 2005; Warren i sur, 2005; IDE, 2008). Neki dokazi upućuju da djeca pokazuju sposobnost kalorijske kompenzacije u različitim uvjetima, ovisno o kalorijskom unosu hrane i energetskim potrebama (povezanim s fizičkom aktivnošću) tijekom dana i/ili tjedna (Warren i sur, 2003; Cecil i sur, 2005). Stoga je vjerojatno da rezultati istraživanja o dnevnom broju obroka naših učenika također posljedica obiteljske rutine učenika, utjecaja medijske promidžbe različitih prehrambenih trendova te energetskih potreba učenika, koje ovise o fizičkoj aktivnosti učenika tijekom dana/tjedna. Važno je napomenuti i da djeca od 6 do 12 godina starosti (za razliku od djece predškolske dobi) imaju značajniju kontrolu nad izborom vlastite prehrane (Tanofsky-Kraff i sur, 2007) te da je u toj dobi prehrambena neofobija (odbijanje ili izbjegavanje novih namirnica) smanjena. Stoga praćenje prehrambenih navika i izbora hrane djece i mladih u razdoblju od šeste do dvanaeste godine života može biti ključno za razumijevanje učinka vlastitog izbora na prehrambene navike pojedinaca.

Iz odgovora učenika sedmog razreda na pitanja ankete "Moje svakodnevne navike“ opaža se da njih šest (od ukupno 20 anketiranih) uopće ne razmišlja o kvaliteti hrane koju konzumira, dok ih samo troje razmišlja o tome je li hrana koju konzumiraju zdrava. Međutim, njih 15 se bavi sportom pa je zabrinjavajuće zašto većina ne razmišlja o kvaliteti svoje prehrane, jer je pravilna prehrana prepoznata kao jedan je od čimbenika koji može pridonijeti tome da sport postane pozitivno iskustvo za djecu i adolescente, ali je i nadasve važna za adekvatan unos energije potrebne za normalan rast uz izraženiju tjelesnoj aktivnosti (Spear, 2005). Izgledno je da su naši učenici toga i svjesni, jer ih polovica navodi da bi željeli promijeniti svoju prehranu u smjeru smanjenog unosa šećera te većeg unosa voća i povrća. I kroz ove odgovore se naslućuje da su stariji učenici voljni razviti zdravije prehrambene navike, kao što to sugeriraju Tanofsky-Kraff i sur. (2007), ali im za to nedostaje više edukacije (što i sami sugeriraju kroz odgovore na anketna pitanja) i intrinzične motivacije, što bi se, prema našem mišljenju, moglo postići primjenom osnovnih načela kvalitetne škole i teorije izbora (Glasser, 1990; Glasser, 1999, 2005) - ne samo u nastavi Prirode i Biologije, već i općenito. Primjerice, kada bismo učenicima nenametljivo, u sklopu neke nastavne teme, predstavili istraživanje koje su proveli Adebamowo i sur. (2005) o pozitivnoj korelaciji između konzumacije određenih prehrambenih proizvoda i pojave akni, učenici koji imaju probleme s aknama bi nakon toga možda i samostalno - vlastitim izborom - pokušali izbaciti određene proizvode iz svoje prehrane i promatrati učinak svog odabira na samima sebi. Ako bi neki učenici na taj način uspjeli spriječiti pojavu akni, to bi ih vjerojatno motiviralo da i ubuduće odabiru namirnice koje im ne uzrokuju akne, a to bi nadalje vjerojatno rezultiralo boljim psihičkim i fizičkim zdravljem učenika te boljom slikom o sebi.

Iz odgovora učenika sedmog razreda na pitanja ankete „Moje mišljenje o temi Pravilna prehrana“, opaža se da postoji interes učenika za temu prehrane, što dodatno opravdava primjenu načela kvalitetne škole i teorije izbora u nastavi biologije, kao što to sugerira naša druga postavljena hipoteza. Kvalitetna škola i teorija izbora temelje se na poučavanju bez prisile, uz suradnički odnos te obostrano uvažavanje interesa učenika i učitelja (Glasser, 1999, 2005). Upravo iz tog razloga je, na drugom dvosatu održanom s učenicima sedmog razreda, nastavni sadržaj prilagođen interesu učenika. 
Primjerice, učenici su u anketama rekli kako bi htjeli učiti više o zdravoj prehrani pa se prilikom obrade poremećaja u prehrani pričalo o zdravoj prehrani kao načinu prevencije nastanka poremećaja u prehrani. Ovakva praksa mogla bi se unaprijediti na način da učenici prije početka izvođenja neke nastavne teme kažu što ih konkretno zanima u sklopu te teme. Tada bi učenici aktivno sudjelovali u kreiranju nastave, a nastavnici bi mogli uklopiti interese učenika u nastavne aktivnosti pojedinih satova, što bi bila dodatna podrška u izgradnji (pozitivnih) stavova učenika i promjeni njihovog ponašanja. To bi zasigurno pomoglo i u stvaranju kvalitetnijeg odnosa između učenika i nastavnika, čime se stvara i pozitivnije okruženje za učenje, što je također jedna od osnovnih postavki kvalitetne škole (Glasser, 1999, 2005). Nadalje, ova anketa je služila je kao povratna informacija nastavniku o uspješnosti provedene nastave, a učenicima je bila oblik samovrednovanja pomoću kojeg su osvijestili uspješnost učenja tijekom nastave, uz naglasak na evaluaciji kvalitete izbora u svakodnevnom životu. Povratna informacija je vrlo važna, jer daje učenicima potvrdu „ispravnosti“ njihovih bilješki i procjene, omogućuje sistematizaciju informacija važnih za ostvarivanje predviđenog odgojno-obrazovnog ishoda i služi učenicima za praćenje i usmjeravanje vlastitog učenja (Penca Palčić, 2008). Također, korištenjem različitih aktivnosti koje podrazumijevaju povećani učenički angažman i samostalnost tijekom poučavanja i učenja, povećava se vjerojatnost učenja, pamćenja, ali i promjene ponašanja učenika, budući da se učenicima omogućuje kontrola nad iskustvom učenja, odnosno ravnopravnost u odabiru, redoslijedu i/ili tempu obrade novih informacija (Markant i sur, 2016).

Prema podatcima iz tablice 2 , primjetne su pozitivne reakcije učenika na provedene nastavne sate, iz čega također možemo naslutiti pozitivne učinke primjene načela kvalitetne škole i teorije izbora na učeničke interese. Međutim, kao što je već prethodno napomenuto, u istraživanju je sudjelovao premali broj učenika da bi ovakvi zaključci bili pouzdani. Kao najznačajniji odgovori mogu se navesti tvrdnje da su učenici shvatili koje navike su im dobre, a koje nisu i da su ih nastavni satovi motivirali da se više brinu o svom zdravlju. Ovakvi odgovori učenika su pokazatelj da bi se i obrada ostalih sadržaja mogla provoditi na način kako je to provedeno u ovom radu (kombinacijom istraživačkog učenja i osnovnih načela teorije izbora i kvalitetne škole).

Iz analize aktivnosti učenika sedmog razreda osnovne škole tijekom provedbe dvosata na temu Pravilna prehrana i Poremećaji u prehrani, opaža se da su učenici bili jako aktivni na satovima, što je dodatni pokazatelj da su nastavni sadržaji i način na koji su se obradili djelovali poticajno na učenike, njihov interes i aktivno sudjelovanje. I Böheim i sur. (2018) su primijenili isti način vrednovanja učeničke aktivnosti na nastavi te su istraživali povezanost motivacije učenika sa podizanjem ruke na nastavi, koje im je predstavljalo bihevioralni indikator motiviranosti učenika i aktivnosti na nastavi. $U$ njihovim istraživanjima sveukupno je sudjelovalo skoro 800 ispitanika, što je izrazito velika razlika u usporedbi sa vrlo malim brojem učenika u istraživanju u našem istraživanju. Međutim, sugeriramo da praćenje učeničke aktivnosti u vidu bilježenja broja podignutih ruku učenika na nastavi može poslužiti kao dobar kriterij za samovrednovanje rada nastavnika - bez obzira na broj učenika u razredu.

\section{ZAKLJUČAK}

Praćenje prehrambenih navika i izbora hrane djece i mladih može biti ključno za razumijevanje stvaranja prehrambenih navika u pojedinaca. Premda je u ovom istraživanju sudjelovao mali broj učenika te rezultati i zaključci stoga nisu dovoljno pouzdani, rezultati učeničkog istraživanja ukazuju da možemo potvrditi našu polaznu pretpostavku da učenici petog i sedmog razreda osnovne škole konzumiraju najmanje tri obroka dnevno i barem jednu vrstu voća ili povrća dnevno. Može se zaključiti da na prehrambene navike učenika koji su sudjelovali u našem istraživanju uvelike utječu podražaji iz 
okoline, poput roditeljske brige i prehrambenih navika roditelja, tradicijske kulture, medija i reklama te dostupnosti, ponude i mogućih ograničenja hrane. Učenici pokazuju interes za temu pravilne prehrane i voljni su razviti zdravije prehrambene navike, ali im za to nedostaje više edukacije i intrinzične motivacije, što bi se moglo postići primjenom osnovnih načela kvalitetne škole i teorije izbora u nastavi. Rezultati istraživačkog rada učenika na temu pravilne prehrane mogli bi utjecati na promjenu vlastitog izbora prehrane učenika, pogotovo ako učenici na samima sebi opaze pozitivne učinke novog izbora, poput boljeg psihičkog i fizičkog zdravlja i/ili bolje slike o sebi. To je upravo i temelj teorije izbora i kvalitetne škole - da se učenici izlažu određenoj situaciji, samostalno prikupljaju informacije o svojim navikama te samostalno donose odluku o tome kako će odgovoriti na prikupljene informacije, odnosno samostalno odabiru svoje buduće ponašanje i/ili korigiraju svoje navike. U jednom dijelu ovog istraživanja, nastavni sadržaj je prilagođen interesu učenika, što je rezultiralo velikom aktivnošću učenika, ukazujući na pozitivne učinke primjene načela kvalitetne škole i teorije izbora u nastavi biologije, koja se temelje se na poučavanju bez prisile, uz suradnički odnos te obostrano uvažavanje interesa učenika i učitelja. Sugeriramo da bi sudjelovanje učenika u kreiranju nastave vjerojatno pomoglo u stvaranju kvalitetnijeg odnosa između učenika i nastavnika i pozitivnijeg okruženja za učenje, što je također jedna od osnovnih postavki kvalitetne škole. Nadalje, predlažemo da nastavnici detaljno bilježe učeničku aktivnost tijekom nastavnih sati, jer bi im to moglo pomoći u samoprocjeni vlastitog rada, kao i u procjeni učeničkog interesa za pojedine nastavne teme i oblike rada.

\section{METODIČKI ZNAČAJ}

Rezultati učeničkih istraživanja provedenih u ovom radu ukazuju na prosječan dnevni broj obroka i zastupljenost pojedinih skupina namirnica u prehrani učenika, što je poslužilo kao dobra osnova za raspravu učenika o temama pravilne prehrane, odnosno za osvješćivanje učenika o njihovim prehrambenim navikama, kao i za izgradnju koncepata i stavova o prehrani na primjerima iz svakodnevnog života. Također, prikupljanje podataka o vlastitoj prehrani, pomoglo je učenicima i u samom procesu učenja, jer su pored bilježenja svojih obroka, učenici morali sami procijeniti je li taj obrok kvalitetan ili ne pa su pritom vjerojatno morali samostalno istražiti dodatne informacije o nutritivnim vrijednostima pojedinih prehrambenim namirnicama. Takvim zadatkom kod učenika se potiče izgradnja predviđenih koncepata i osvješćivanje svojih navika, odnosno razvoj kritičkog mišljenja i sposobnost samoprocjene, što može potaknuti učenike na pozitivne promjene u njihovom ponašanju (npr. u izboru prehrambenih namirnica). Ako se potom na nastavi provodi analiza rezultata istraživačkog rada učenika, kao što je provedeno u ovom radu, osigurava se kvalitetna povratna informacija učenicima, koja je vrlo važna za usmjeravanje vlastitog učenja. Stoga, provedbom ankete tipa „Moje mišljenje o temi Pravilna prehrana“, učenici provode samoprocjenu vlastitih postignuća tijekom nastavnog sata, osvješćuju vlastite svakodnevne izbore i navike koje se mogu reflektirati na njihovo zdravlje te ukazuju na teme, o kojima bi voljeli doznati više, što je vrijedna informacija za njihovog nastavnika.

Primjeri nastave poput ovih opisanih u ovom radu mogu se iskoristiti kao smjernice nastavnicima kako bi se mogla kreirati istraživanja i nastava vezana uz temu Prehrana. Velika prednost ovakvih istraživanja je što kroz njih nastavnik može bolje upoznati učenike i saznati neke od njihovih dobrih i loših prehrambenih navika. Primjerice, kroz istraživanje provedeno među učenicima petog razreda osnovne škole, koje je opisano u ovom radu, nastavnik je mogao primijetiti tendenciju konzumiranja voća neposredno nakon ručka, što i nije najbolje iz perspektive iskoristivosti hranjivih tvari iz voća. Bilo bi poželjno da učenici tek sat vremena nakon ručka pojedu voće, kako bi se hranjivi sastojci iz voća 
probavom mogli bolje iskoristiti i preraditi. Stoga je pri razgovoru s učenicima tijekom poučavanja napravljen naglasak upravo na toj činjenici, kako bi se pokušalo utjecati da učenici promijene svoje navike na osnovu ostvarenog učenja. Među učenicima sedmog razreda je opaženo da samo $15 \%$ učenika razmišlja o zdravoj prehrani, a 50 \% učenika je reklo da bi htjeli promijeniti nešto u svojoj prehrani. I u ovom slučaju se kroz razgovor s učenicima koji su iskazali želju za uvođenjem promjena u svoju prehranu ukazalo na mogućnost različitih izbora u prehrani temeljem kojih sami učenici mogu odlučiti o najprihvatljivijoj opciji. Promjena na bolje je bila vidljiva već nakon dva održana dvosata, gdje su učenici izjavili kako im je nastava pomogla da spoznaju važnost brige o zdravlju i kvalitete vlastitih izbora i navika. No, pri poučavanju nastavnici trebaju biti svjesni da je za dugotrajnu promjenu navika i ponašanja učenika potrebno dugotrajnije poučavanje učenika od ovdje prikazanog.

S obzirom na to da je tijekom provedbe ovog istraživanja konstantan problem bio premali broj učenikaispitanika, jedno od rješenja za sustavno praćenje prehrambenih navika učenika mogao bi biti nacionalni program po uzoru na GLOBE program (The Program GLOBE, 2020). U sklopu takvog programa, nastavnici u cijeloj Hrvatskoj mogli bi bilježiti podatke vezane uz prehranu učenika, ukoliko bi provodili ovakva istraživanja. Prednost ovih istraživanja je što ne zahtijevaju nikakvu posebnu istraživačku opremu pa se mogu provoditi u bilo kojoj školi. U tom slučaju bismo prikupili bazu podataka koja bi uključivala sve informacije važne za analizu prehrane učenika, uključujući dob i regiju u kojoj se učenici nalaze. Mogla bi se istraživati i konzumacija određene hrane ili samo nekih namirnica i/ili pojedinih obroka. Ukoliko bi program bio višegodišnji, mogle bi se uspoređivati i razlike među generacijama te bi i sami učenici mogli i uspoređivati različite skupine podataka, što bi moglo dodatno potaknuti učenike na „zdrave“ promjene u njihovom načinu prehrane i stavovima uz prehrambene navike. Međutim, prije provođenja takvog programa, učenicima bi se trebale dati jasne i detaljne upute kako bilježiti svoje prehrambene navike, ali i savjetovati se s psiholozima, kako bi se izbjegli neželjeni opsesivno-kompulzivni poremećaji u prehrani kod djece i mladih.

\section{ZAHVALA}

Veliku zahvalnost, u prvom redu, dugujemo prof.dr.sc. Ines Radanović, čija je ideja da objavimo navedeni članak koji je nastao na osnovu seminarskih radova izrađenih u sklopu kolegija Metodička praksa nastave biologije. Njen velik angažman i dragocjena pomoć u pisanju članka doveli su do vidljivih rezultata. Zahvaljujemo se na danoj prilici i ispunjenju želje za objavljivanjem članka u časopisu Educatio Biologiae. Nadalje, veliko hvala i dr. sc. Damiru Sirovini na nesebičnom pomaganju, dobronamjernim savjetima i zalaganju u što boljoj analizi i provedbi navedenog članka. Hvala svom nastavnom osoblju i svim kolegicama i kolegama studentima na izgradnji stavova te promicanju i realizaciji ideja u sustavu školstva koje smo stekli na kolegijima Metodika nastave biologije i Metodička praksa nastave biologije. Hvala na neizmjernoj pomoći i poticaju da postanemo što bolji nastavnici i suradnici s učenicima u nastavi prirodoslovlja.

\section{LITERATURA}

Adebamowo, C. A., Spiegelman, D., Danby, W., Frazier, L., Willett, C. W., Holmes, M. D. (2005). High school dietary dairy intake and teenage acne. Journal of the American Academy of Dermatology, 52, 207-214.

Böheim, R., Knogler, M., Kosel, C., Seidel, T. (2020). Exploring student hand-raising across two school subjects using mixed methods: An investigation of an everyday classroom behavior from a motivational perspective. Learning and Instruction, 65, 1-16.

Braithwaite, I., Stewart, A. W., Hancox, R. J., Beasley, R., Murphy, R., Mitchell, E. A. (2014). Fast-food consumption and body mass index in children and adolescents: an international cross-sectional study. BMJ Open, 4:e005813.

Cecil, J. E, Palmer, C. N., Wrieden, W., Murrie, I., Bolton-Smith, C., Watt, P., Wallis, D. J., Hetherington, M. M. (2005). Energy intakes of children after preloads: adjustment, not compensation. The American Journal of Clinical Nutrition, 82, 302-8.

Dewey, J. (1997). (1997). Experience and education. Touchstone, New York. 
Dobročinac, M., Devčić, B., Lovrić, B. (2019). Prehrambene navike, nutritivni status i zdravi stilovi života kod adolescenata na području Vinkovaca. Hrana u zdravlju i bolesti: znanstveno-stručni časopis za nutricionizam i dijetetiku, specijalno izdanje, 14.

Fairburn, 2008 Fairburn, C. G. (2008). Cognitive Behavior Therapy and Eating Disorders. Guilford Press, New York.

Fisher, J. O., Birch, L. L. (2002). Eating in the absence of hunger and overweight in girls from 5 to $7 \mathrm{y}$ of age. The American Journal of Clinical Nutrition, 76, 226-31.

Gazibara, S. (2018). Aktivno učenje kao didaktičko-metodička paradigma suvremene nastave. Doktorski rad. Filozofski fakultet, Sveučilište u Zagrebu, Zagreb.

Gidding, S. S., Dennison, B. A., Birch, L. L., Daniels, S. R., Gillman, M. W., Lichtenstein, A. H., Rattay, K. T., Steinberger, J., Stettler, N., Van Horn, L.; American Heart Association (2006). Dietary recommendations for children and adolescents: a guide for practitioners. Pediatrics, 117, 544-59.

Glasser, W. (1999). Nastavnik u kvalitetnoj školi. Educa, Zagreb.

Glasser, W. (2005). Kvalitetna škola; Škola bez prisile. Educa, Zagreb.

Glasser, W. (1990). Reality Therapy: A New Approach to Psychiatry. Harper \& Row, New York.

IDE (Indiana Department of Education) (2008). What's in a Meal? Healthy Hoosier Edition. The CACFP Resource Manual for Providing Creditable and Nutritious Meals. Dostupno na: https://www.childcareanswers.com/cca/images/whatsinameal.pdf, pristupljeno 2.12.2020.

Johnson, J. G., Cohen, P., Kasen, S., Brook, J. S. (2002). Eating Disorders During Adolescence and the Risk for Physical and Mental Disorders During Early Adulthood. Archives Of General Psychiatry, 59, 545-552.

Markant, D. B., Ruggeri, A., Gureckis, T. M., Xu, F. (2016). Enhanced memory as a common effect of active learning. Mind, Brain, and Education, 10, 142-152.

Ministarstvo znanosti i obrazovanja (2019a). Kurikulum za nastavni predmet Prirode za osnovne škole u Republici Hrvatskoj. NN 7/2019. Dostupno na: https://narodne-novine.nn.hr/clanci/sluzbeni/2019 017 148.html, pristupljeno 2.12.2020.

Ministarstvo znanosti i obrazovanja (2019b). Kurikulum za nastavni predmet Biologije za osnovne škole i gimnazije u Republici Hrvatskoj. NN 7/2019. Dostupno na: https://narodne-novine.nn.hr/clanci/sluzbeni/2019 017 149.html, pristupljeno 2.12.2020.

Ministarstvo znanosti i obrazovanja (2019c). Kurikulum za međupredmetnu temu Zdravlje za osnovne i srednje škole u Republici Hrvatskoj. NN 10/2019. Dostupno na: https://narodne-novine.nn.hr/clanci/sluzbeni/2019 0110 212.html, pristupljeno 20.12.2020.

Ministarstvo znanosti i obrazovanja (2019d). Kurikulum za međupredmetnu temu Održivi razvoj za osnovne i srednje škole u Republici Hrvatskoj. NN 7/2019. Dostupno na: https://narodne-novine.nn.hr/clanci/sluzbeni/2019 017 152.html, pristupljeno 2.12.2020.

Ministarstvo znanosti i obrazovanja (2020). Modeli i preporuke za rad u uvjetima povezanima s COVID-19. Dostupno na: https://mzo.gov.hr/UserDocsImages/dokumenti/Modeli\%20i\%20preporuke\%20za\%20provedbu\%20nastave\%20u\%2020202021\%20(29.8.2020).pdf, pristupljeno 2.12.2020.

Pala, V., Reisch, L. A., Lissner, L. (2019). Dietary behaviour in children, adolescents and families: the eating habits questionnaire (EHQ). U: Bammann, K., Lissner, L., Pigeot, I., Ahrens, W. (ur.). Instruments for Health Surveys in Children and Adolescents. Springer Series on Epidemiology and Public Health. Springer, Cham.

Penca Palčić, M. (2008). Utjecaj provjeravanja i ocjenjivanja znanja na učenje. Život i škola, 19, UDK 371.26 Dostupno na: https://hrcak.srce.hr/file/37938, pristupljeno 2.12.2020.

Serra-Majem, L., García-Closas, R., Ribas, L., Pérez-Rodrigo, C., Aranceta, J. (2001). Food patterns of Spanish schoolchildren and adolescents: The enKid Study. Public Health Nutrition, 4, 1433-1438.

Skrzypulec-Plinta, V., Bak-Sosnowska, M. (2012). Eating habits and physical activity of adolescents in Katowice - the teenagers' declaration vs. Their parents' beliefs. Journal of clinical nursing, 21, 2461-2468.

Spear, B. (2005). Sports nutrition. U: Stang, J., Story, M. (ur.). Guidelines for Adolescent Nutrition Services. Pp. 199 - 208. Dostupno na: http://www.epi.umn.edu/let/pubs/adol book.shtm, pristupljeno 2.12.2020.

Tanofsky-Kraff, M., Haynos, A. F., Kotler, L. A., Yanovski, S. Z., Yanovski, J. A. (2007). Laboratory-based studies of eating among children and adolescents. Current Nutrition \& Food Science, 3, 55-74.

The Program GLOBE (2020). The Program GLOBE. Dostupno na: https://www.globe.gov/, pristupljeno 15.2.2020.

Vrcelj, Ž. (2015). Projektni zadatci - suradničko učenje. Poučak, 16, 60-72.

Warren, J. M., Henry, C. J., Simonite, V. (2003). Low glycemic index breakfasts and reduced food intake in preadolescent children. Pediatrics, 112(5):e414.

Warren, C. S., Strauss, J., Taska, J. L., Sullivan, S. J. (2005). Inspiring or dispiriting? The effect of diet commercials on snack food consumption in high school and college-aged women. International Journal of Eating Disorders, 37, $266-70$.

Wubbolding, R. E. (2007). Glasser Quality School. Group Dynamics: Theory, Research, and Practice, 11, 253-261.

\section{PRILOZI}

Prilog 1 Anketa "Moje svakodnevne navike“

1. Spol

○ Muško

- Žensko

2. Koliko imaš godina? 
3. Bavim se sportom.
○ $\mathrm{Da}$
○ $\mathrm{Ne}$

4. S prijateljima i prijateljicama češće:

- Družim se u parku ili u gradu

- Dopisujemo se ili igramo igrice

5. Koliko obroka imaš dnevno?

6. Međuobroke imam:
- Svaki dan
- Ponekad
- Nikad

7. Svaki dan jedem povrće.
$\begin{array}{lllll}\mathrm{Da} & 1 & 2 & 3 & \mathrm{Ne}\end{array}$

8. Svaki dan jedem voće.

$\mathrm{Da} \quad 1 \quad 2 \quad 3 \quad \mathrm{Ne}$

9. Nakon obroka se i dalje osjećam gladno.

$\begin{array}{lllll}\text { Često } & 1 & 2 & 3 & \text { Rijetko }\end{array}$

10. Kada jedem nešto ukusno, pojedem previše hrane.
$\begin{array}{lllll}\text { Često } & 1 & 2 & 3 & \text { Rijetko }\end{array}$

11. Mislim da se hranim zdravo.

$\begin{array}{lllll}\mathrm{Da} & 1 & 2 & 3 & \mathrm{Ne}\end{array}$

12. Prilikom odabira hrane razmišljam je li ta hrana zdrava ili nije.

$\begin{array}{lllll}\mathrm{Da} & 1 & 2 & 3 & \mathrm{Ne}\end{array}$

13. Htjela / htio bih nešto promijeniti u svojoj prehrani.

○ $\mathrm{Da}$

$\circ \mathrm{Ne}$

14. Ako da, što bi htjela / htio promijeniti u svojoj prehrani?

15. O kojim temama vezanim uz prehranu bi htjela / htio više naučiti?

Prilog 2 Anketa „Moje mišljenje o temi Pravilna prehrana“

1. Spol
○ Muško
- Žensko

2. O temi pravilne prehrane naučila / naučio sam:
- Više nego što sam mislila / mislio
- Koliko sam očekivala / očekivao
- Manje nego što sam očekivala / očekivao

3. Nastavni satovi su me potaknuli da više istražim o temi prehrane:
○ $\mathrm{Da}$
- Možda
○ $\mathrm{Ne}$

4. Nastavni satovi su me potaknuli da više razmišljam o zdravim navikama:
○ $\mathrm{Da}$
- Možda
○ $\mathrm{Ne}$

5. Nastavni satovi su mi pomogli da shvatim koje navike su mi dobre, a koje bih trebala promijeniti:
○ Da
- Možda
- $\mathrm{Ne}$

6. Nakon ovih nastavnih satova više ću se truditi pravilno se hraniti:
○ Da
- Možda
- $\mathrm{Ne}$

7. Nastavni satovi su me motivirali da se više brinem o svom zdravlju:
○ $\mathrm{Da}$
○ Možda
- $\mathrm{Ne}$

8. Nastavni satovi su me motivirali da prijateljima i obitelji pričam o važnosti pravilne prehrane:
○ $\mathrm{Da}$
○ Možda 


\section{○ $\mathrm{Ne}$}

9. Najkorisnija informacija koju sam naučila / naučio je:

10. Informacija koja mi nije bila korisna:

11. O kojim smo temama trebali više razgovarati?

12. Koja te tema vezana uz pravilnu prehranu počela zanimati nakon nastavnih satova?

Prilog 3 Pitanja iz kviza o prehrani napravljenog na internetskoj stranici Socrative

1. Koliko bismo obroka trebali imati dnevno?
a) $0-2$
b) $3-5$
c) 6-8

2. Masnoće su sastavni dio pravilne prehrane.
a) $\mathrm{Da}$
b) $\mathrm{Ne}$

3. Izbaci uljeza!

Pravilnu prehranu čini:
a) Puno voća i povrća
b) Raznovrsne namirnice
c) Umjerene količine masnoća
d) Puno slatkiša

4. Osobe koje pate od anoreksije se:

a) Izgladnjuju i puno vježbaju

b) Prejedaju pa povraćaju

5. Osobe koje imaju poremećaj kompulzivnog prejedanja:
a) Često su premršave
b) Često imaju problema sa viškom kilograma
c) Dobro se nose sa stresom i problemima

6. U kojoj od ovih namirnica se može pronaći puno skrivenog šećera?
a) Piletina
b) Puding od vanilije
c) Običan jogurt 


\title{
Teaching the topic Human nutrition through learning by research and basic principles of choice theory and quality school
}

\author{
Ana Petelinec, Ema Nikša, Dominik Grudiček, Mirela Sertić Perić \\ apetelinec@stud.biol.pmf.hr \\ University of Zagreb, Faculty of Science, Department of Biology, Zagreb, Croatia; ORCID: 0000-0002-4744-7884
}

\begin{abstract}
Malnutrition is a growing problem in modern societies and is already occurring among children and adolescents. The main goal of this study was to point out the methods and forms of teaching that can be used to raise awareness of the importance of healthy nutrition among primary school students. Student research on the nutrition of fifth and seventh grade elementary school students was conducted to investigate the daily meals and the diversity of students' nutrition. Based on the research results, by adapting teaching activities to students' interests, students were guided in learning about healthy eating habits. The results of student research showed that students who participated in the study daily consumed at least three meals and at least one type of fruit or vegetable. We link these findings to previous research explaining that children's and young people's eating habits are greatly influenced by various environmental factors, such as parents' eating habits, traditions and media. The results of the student research served as a basis for further teaching on the topic of healthy human nutrition, i.e. for building predicted biological concepts and student attitudes, and for developing the ability of applying the acquired knowledge about nutrition on everyday life examples. During the teaching activities, students expressed their interest in the topic of healthy nutrition and in developing healthier eating habits. We are of opinion that this could be achieved by applying the basic principles of quality school and theory of choice during teaching, which is based on students independently choosing their future behavior and/or on correcting their existing habits, based on information they independently collect and process. In one part of this research, the teaching content was adjusted to the student interests, which resulted in increased student activity, pointing to the positive effects of applying the principles of quality school and choice theory in teaching biology. We suggest that student participation in creating lessons would probably help to create a better relationship between students and teachers and a more positive learning environment, which is also one of the quality school basic settings. In addition, greater student involvement in creating lessons can support building (positive) student attitudes or encourage positive changes in behavior (food choices) of students. Furthermore, based on the results of this research, we suggest that teachers record student activity in detail during classes. It could help them in self-assessment of their work, as well as in assessing student interest in certain teaching topics and forms of work.
\end{abstract}

Keywords: student nutrition; biology teaching; student research; choice of possibilities 